Article

\title{
Lambertianic Acid Sensitizes Non-Small Cell Lung Cancers to TRAIL-Induced Apoptosis via Inhibition of XIAP/NF- $K B$ and Activation of Caspases and Death Receptor 4
}

\author{
Deok Soo Ahn ${ }^{\dagger}$, Hyo Jung Lee ${ }^{\dagger}$, Jisung Hwang, Hyukgyu Han, Bonglee Kim ${ }^{\circledR}$, BumSang Shim \\ and Sung-Hoon Kim * (i) \\ College of Korean Medicine, Kyung Hee University, Seoul 02447, Korea; crowduk@hanmail.net (D.S.A.); \\ hyonice77@naver.com (H.J.L.); hjsung0103@naver.com (J.H.); bodyline740@nate.com (H.H.); \\ bongleekim@khu.ac.kr (B.K.); eshimbs@khu.ac.kr (B.S.) \\ * Correspondence: sungkim7@khu.ac.kr; Tel.: +82-2-961-9233 \\ + These authors contributed equally to this work.
}

Received: 18 April 2018; Accepted: 14 May 2018; Published: 16 May 2018

\begin{abstract}
Lambertianic acid (LA) is a biologically active compound from the leaves of Pinus koraiensis. In the present study, apoptotic mechanisms of LA plus TNF-related apoptosis-inducing ligand (TRAIL) were elucidated in non-small cell lung cancer cells (NSCLCs). Cytotoxicity assay, flow cytometry, immunoprecipitation, and Western blotting were performed. Here, combined treatment of LA and TRAIL increased cytotoxicity, sub-G1 population, cleaved poly (ADP-ribose) polymerase (PARP), and caspase3/8/9 in A549 and H1299 cells compared to LA or TRAIL alone. Furthermore, combined treatment of LA and TRAIL significantly decreased antiapoptotic proteins such as B-cell lymphoma 2 (Bcl-2), Fas-like inhibitor protein (FLIP), and X-linked inhibitor of apoptosis protein (XIAP), and enhanced the activation of proapoptotic proteins Bid compared to LA or TRAIL alone. In addition, combined treatment of LA and TRAIL upregulated the expression of Death receptor 4 (DR4) and downregulated phosphorylation of nuclear factor k-light-chain-enhancer of activated B cells (p-NF-kB), inhibitory protein of kB family (p-IkB), and FLIP in A549 and H1299 cells along with disrupted binding of XIAP with caspase3 or NF- $\mathrm{kB}$. Overall, these findings suggest that lambertianic acid enhances TRAIL-induced apoptosis via inhibition of XIAP/NF- $\mathrm{kB}$ in TRAIL resistant NSCLCs.
\end{abstract}

Keywords: non-small cell lung cancer; lambertianic acid; apoptosis; TRAIL; XIAP; NF-кB

\section{Introduction}

The death ligand TRAIL (tumor necrosis factor-related apoptosis-inducing ligand), a member of the TNF superfamily, induces apoptosis in cancer cells with low toxicity and less resistance in normal cells [1]. TRAIL activation is mainly induced by binding to the DR4 and DR5 and subsequently leads to death-inducing signaling complexes (DISCs) via FAS-associated protein and caspase-8 protein leading to activation of apoptotic cell death $[2,3]$. Though TRAIL is an important anticancer agent, TRAIL resistance is a major limitation to effective cancer therapy $[4,5]$. Therefore, development of combination treatments to overcome resistance to TRAIL is requested for effective cancer therapy. Notably, non-small cell lung cancer cell lines such as A549, H1299, and H596 cells are known to be resistant to TRAIL-induced apoptosis [6]. Recently, several groups reported the synergistic or additive effect of phytochemicals, such as kaempferol [7], angelicin [8], and curcumin [9], on TRAIL-induced apoptosis. 
Lambertianic acid (LA) (Figure 1a), a major active constituent of Pinus koraiensis, has been reported to have antiobesity [10], anti-inflammatory [11], and anticancer effects [12]. Nevertheless, the underlying apoptotic mechanism of LA as a TRAIL sensitizer has never been demonstrated. In the present study, the sensitizing mechanism of LA in TRAIL-induced apoptosis was investigated as a novel strategy to overcome the resistance of cancer cells to apoptosis in A549 and H1299 NSCLCs.

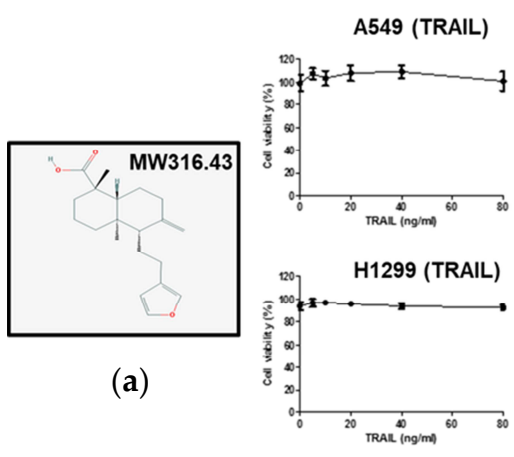

(b)

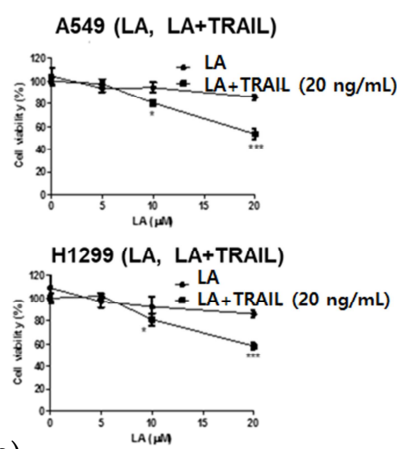

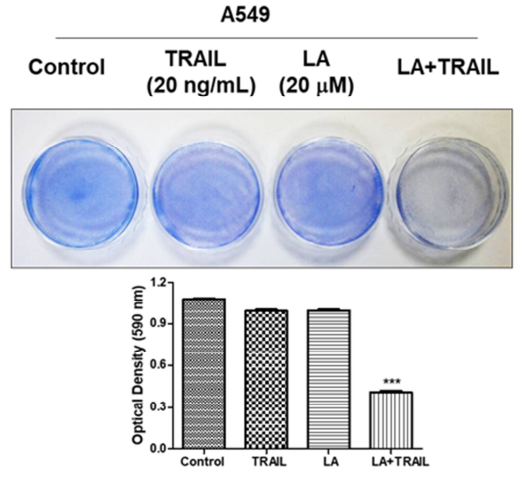

(c)

Figure 1. Cytotoxicity of the combination of lambertianic acid (LA) and tumor necrosis factor-related apoptosis-inducing ligand (TRAIL) in A549 and H1299 non-small cell lung cancer cells. (a) Chemical structure of LA. Molecular weight $=316.43$. (b) Cell viability was evaluated by 3-(4,5-dimethylthiazol-2-yl)-2,5-diphenyltetrazolium bromide (MTT) assay. Cells were seeded onto 96 well microplates and treated with various concentrations of LA $(0,5,10,20 \mu \mathrm{M})$ and TRAIL $(0,20,40,80 \mathrm{ng} / \mathrm{mL})$ for $24 \mathrm{~h}$. The cytotoxic effects of LA $(20 \mu \mathrm{M})$ and TRAIL $(20 \mathrm{ng} / \mathrm{mL})$ on TRAIL in A549 and H1299 cells. Data represent means \pm SD. ${ }^{*} p<0.05,{ }^{* * *} p<0.001$ versus LA-treated control $(n=3)$. (c) A549 cells were treated with LA $(20 \mu \mathrm{M})$ and/or TRAIL $(20 \mathrm{ng} / \mathrm{mL})$ for $24 \mathrm{~h}$ and then stained with crystal violet. Data represent means \pm SD. ${ }^{* * *} p<0.001$ versus TRAIL alone $(n=4)$.

\section{Results}

\subsection{Combined Treatment of LA and TRAIL Enhanced Cytotoxicity in A549 and H1299 Non-Small Cell Lung Cancer Cells}

The cytotoxicity of LA in A549 and H1299 non-small cell lung cancer cells was evaluated by MTT assay. As shown in Figure 1b, combined treatment of LA $(20 \mu \mathrm{M})$ and TRAIL ( $20 \mathrm{ng} / \mathrm{mL})$ for $24 \mathrm{~h}$ showed significantly cytotoxicity in A549 and H1299 cells compared to treatment with LA or TRAIL alone (Figure 1b). Also, a cell proliferation assay using crystal violet staining revealed that combined treatment of LA $(20 \mu \mathrm{M})$ and TRAIL $(20 \mathrm{ng} / \mathrm{mL})$ significantly inhibited proliferation in A549 cells compared to treatment with LA or TRAIL alone (Figure 1c).

\subsection{Combined Treatment of LA and TRAIL Significantly Increased the Sub-G1 Population and Also Increased} the Cleavage of PARP and Caspase8/9/3 in A549 and H1299 Non-Small Cell Lung Cancer Cells

To confirm the apoptotic effect of combined treatment of LA and TRAIL, Western blot assay and cell cycle analysis were performed in A549 and H1299 cells treated by combined treatment of LA and TRAIL. Combined treatment of LA and TRAIL increased sub-G1 population in A549 and H1299 cells (Figure 2a) and also increased the cleavage of PARP and caspase8/9/3 and decreased the expression of pro-PARP and pro-caspase8/9/3 in A549 and H1299 cells compared to LA or TRAIL alone (Figure 2b). To confirm the involvement of caspases, A549 and H1299 cells were pretreated with caspase inhibitors for $1 \mathrm{~h}$ prior to the cotreatment. Here, pan caspase inhibitor (z-VAD-fmk) and caspase-8 inhibitor (z-IETD-fmk) significantly blocked the increase of sub-G1 population by combined treatment of LA and TRAIL (Figure 2a). Consistently, a cell apoptosis assay using Annexin-V/PI double staining revealed that combined treatment of LA $(20 \mu \mathrm{M})$ and TRAIL $(20 \mathrm{ng} / \mathrm{mL})$ for $24 \mathrm{~h}$ significantly increased the 
early and late apoptosis to $37.50 \%$ and $17.88 \%$ in A549 cells, and $17.43 \%$ and $4.96 \%$ in $\mathrm{H} 1299$ cells, respectively, compared to LA $(20 \mu \mathrm{M})$ or TRAIL $(20 \mathrm{ng} / \mathrm{mL})$ alone by Annexin V and propidium iodide (PI) staining (Figure 2c).
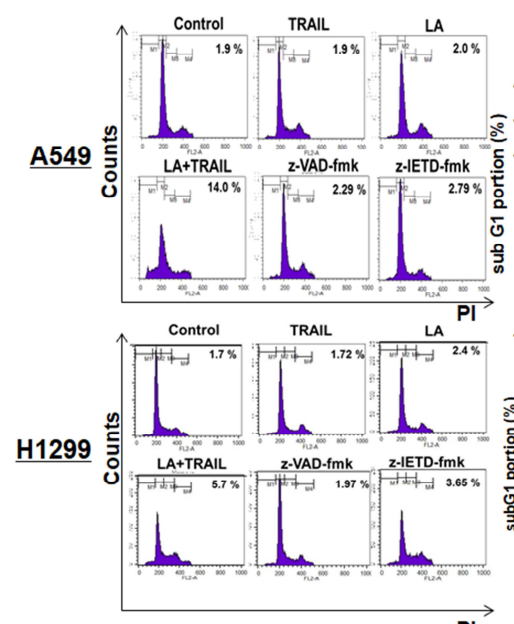

$\overrightarrow{P I}(a)$
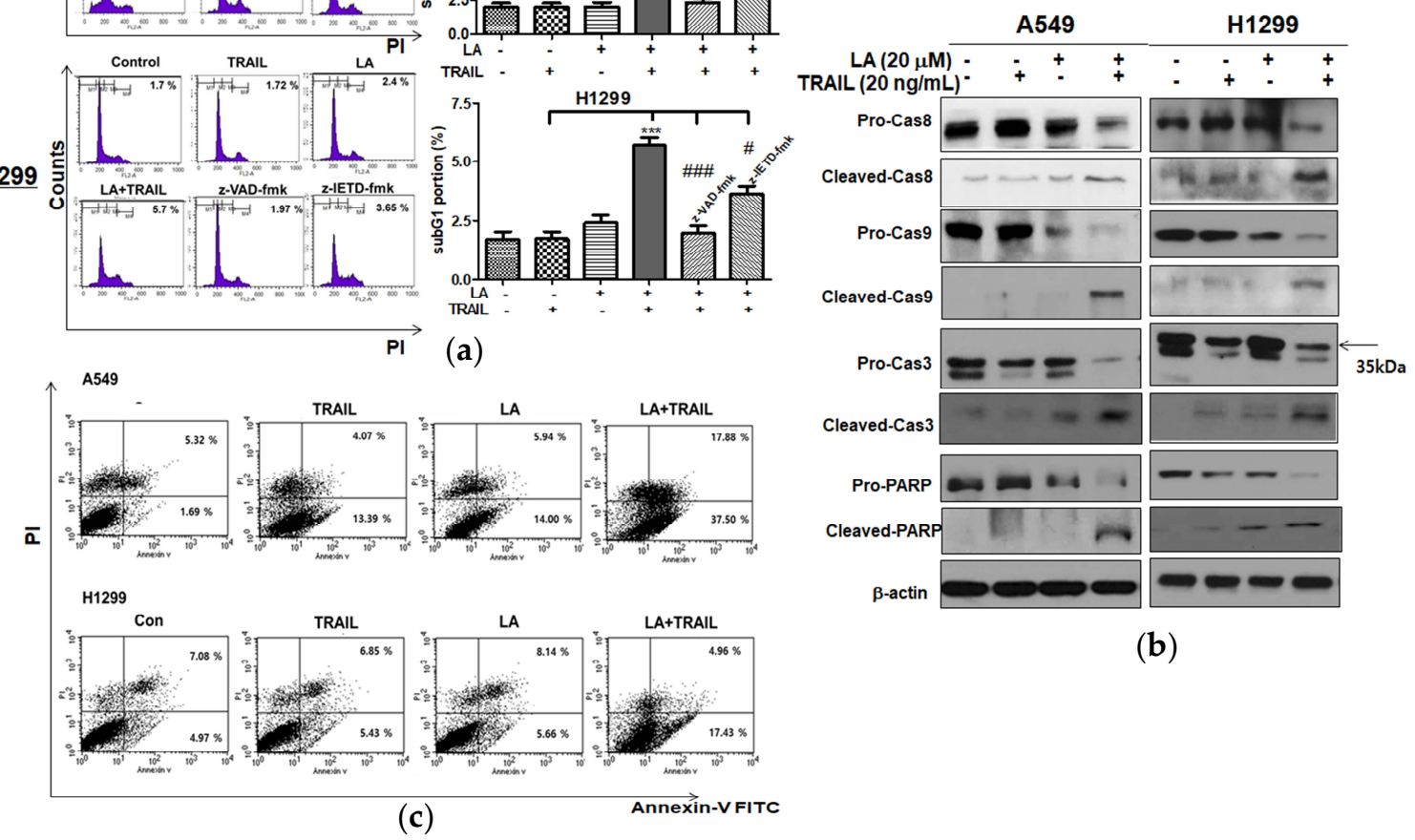

(b)

Figure 2. Combined effect of LA and TRAIL on the sub-G1 population and apoptotic proteins in A549 and H1299 non-small cell lung cancer cells. (a) Cells were treated with LA (20 $\mu$ M) and/or TRAIL (20 ng/mL) for $24 \mathrm{~h}$. The treated cells were fixed with $70 \%$ ethanol, stained with propidium iodide (PI) and analyzed by flow cytometry with or without with caspase inhibitors (pan caspase inhibitor; z-VAD-fmk $(80 \mu \mathrm{M})$, caspase-8 inhibitor; z-IETD-fmk $(50 \mu \mathrm{M}))$. Bar graphs show quantification of cell cycle population (\%). Data represent means \pm SD. ${ }^{* *} p<0.001$ versus TRAIL alone, $\# p<0.05$, \#\#\# $p<0.001$ versus LA+TRAIL treated control. $(n=3))$. (b) Cells were treated with LA $(20 \mu \mathrm{M})$ and/or TRAIL (20 ng/mL) for $24 \mathrm{~h}$. Cell lysates were prepared and subjected to Western blotting for procaspase-8,9,3, Pro-PARP, cleaved caspase-8,9,3, and cleaved-PARP. (c) Cells were treated with LA $(20 \mu \mathrm{M})$ and/or TRAIL $(20 \mathrm{ng} / \mathrm{mL})$ for $24 \mathrm{~h}$. The cells were stained using FITC-Annexin V/PI dye and early and late apoptotic portions were detected by flow cytometry.

\subsection{Combined Treatment of LA and TRAIL Regulated Antiapoptotic and Proapoptotic Proteins in A549 and} H1299 Non-Small Cell Lung Cancer Cells

To determine whether cotreatment of LA and/or TRAIL affects apoptosis, we assessed the expression levels of proapoptotic and antiapoptotic proteins by Western blotting. Combined treatment of LA and TRAIL attenuated the expression of Bid and Bcl-2 in A549 and H1299 cells (Figure 3a). Consistently, combined treatment of LA and TRAIL effectively blocked the expression of X-linked inhibitor of apoptosis protein (XIAP) in A549 and H1299 cells compared to LA or TRAIL alone (Figure 3b). 

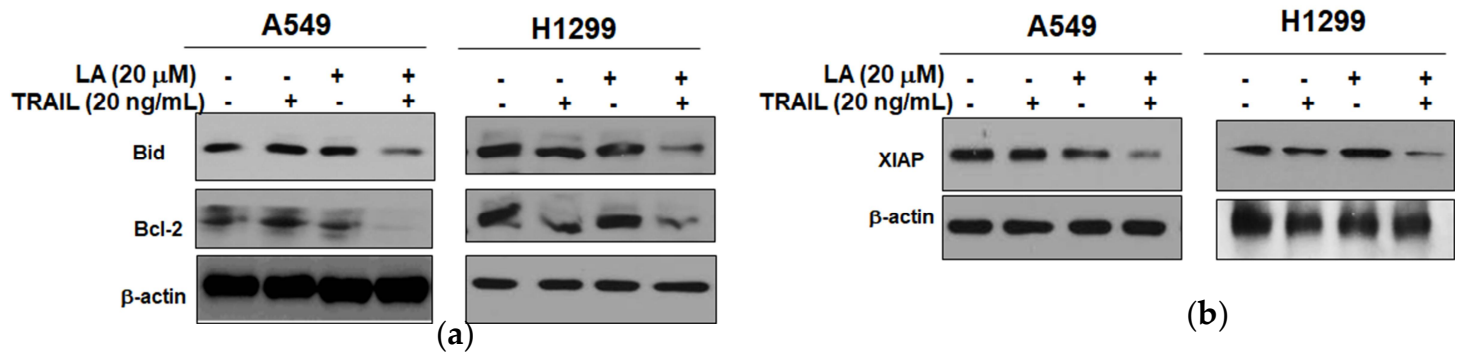

(b)

Figure 3. Combined effect of LA and TRAIL on antiapoptotic and proapoptotic proteins in A549 and H1299 non-small cell lung cancer cells. (a,b) Cells were treated with LA (20 $\mu$ M) and/or TRAIL (20 ng/mL) for $24 \mathrm{~h}$. Cell lysates were prepared and subjected to Western blotting for Bid, Bcl-2, and XIAP.

2.4. Combined Treatment of LA and TRAIL Upregulated the Expression of DR4 and Inhibited the Expression of

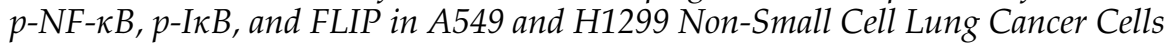

We examined the expression of TRAIL death receptors and its associated proteins such as DR4 and DR5 by Western blotting. Combined treatment of LA and TRAIL upregulated the expression of DR4, but not DR5 in A549 and H1299 cells compared to LA or TRAIL alone (Figure 4a). Also, to clarify the role of NF- $\mathrm{kB}$ signaling in TRAIL-induced apoptosis, Western blotting was conducted in A549 and H1299 cells treated with combined treatment of LA and TRAIL. Combined treatment of LA and TRAIL attenuated the expression of p-NF-kB and p-IкB in A549 and H1299 cells compared to LA or TRAIL alone (Figure 4b). Next, the effect of TRAIL and/or LA was examined on the expression of TRAIL associated proteins such as FLIP, DcR1, and DcR2 by Western blotting. As shown in Figure $4 \mathrm{c}$, combined treatment of LA $(20 \mu \mathrm{M})$ and TRAIL $(20 \mathrm{ng} / \mathrm{mL})$ synergistically downregulated the expression of FLIP, but not DcR1 and DcR2, compared to LA or TRAIL alone.
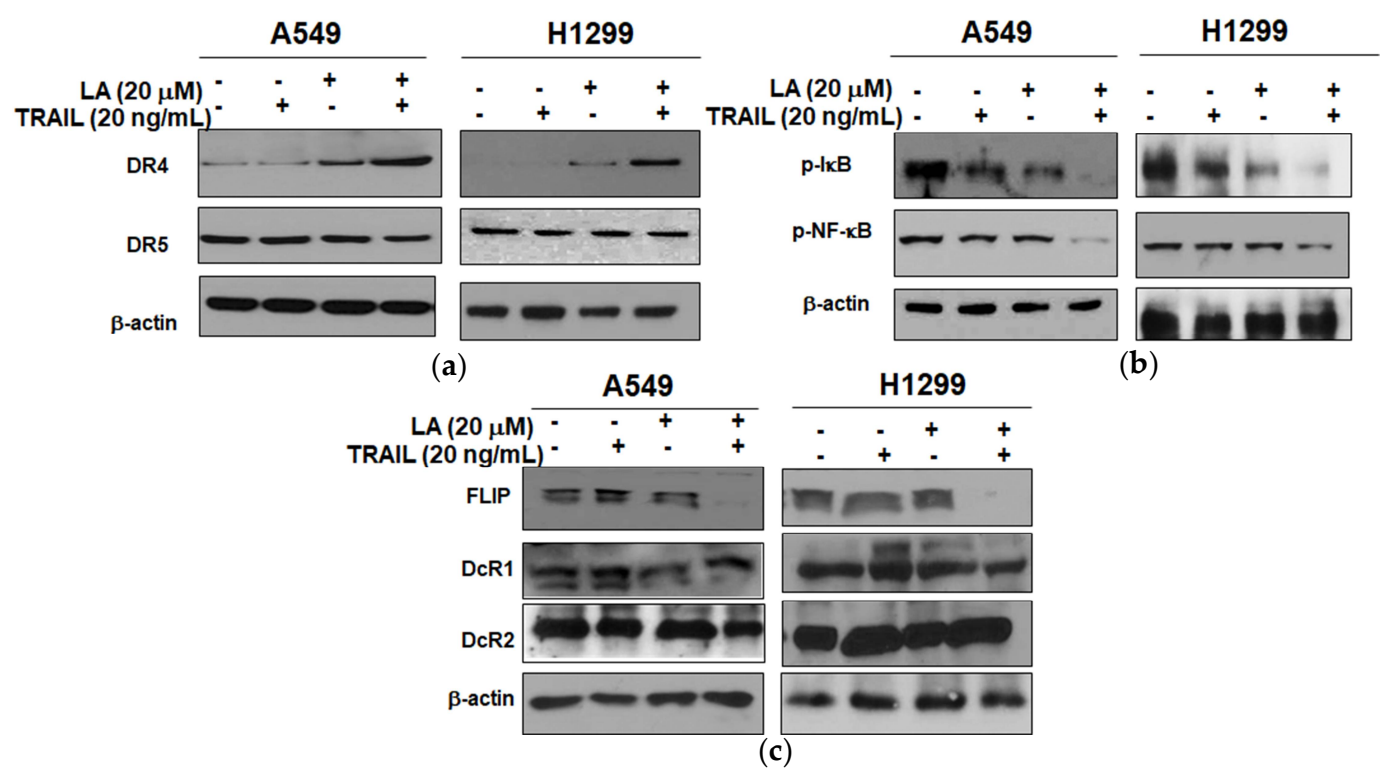

(b)

Figure 4. Combined effect of LA and TRAIL on the expression of DR4, p-NF-kB, p-IкB, and FLIP in A549 and H1299 cells. Cells were treated with LA ( $20 \mu \mathrm{M})$ and/or TRAIL ( $20 \mathrm{ng} / \mathrm{mL})$ for $24 \mathrm{~h}$ and cell lysates were prepared and subjected to Western blotting. (a) Combined effect of LA and TRAIL on the expression of DR4 and DR5 in A549 and H1299 cells. (b) Combined effect of LA and TRAIL on the

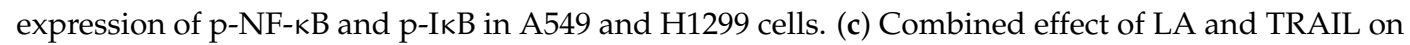
the expression of FLIP, DcR1, and DcR2 in A549 and H1299 cells. 
2.5. Combined Treatment of LA and TRAIL Disrupted Binding of XIAP with Caspase3 and NF- $\kappa B$ in A549 Non-Small Cell Lung Cancer Cells

To confirm the XIAP, caspase3, and NF-kB interaction inhibition of combined treatment of LA and TRAIL, immunoprecipitation was performed in A549 cells treated with combined treatment of LA and TRAIL. Protein-protein interaction (PPI) scores of XIAP and caspase 3 with NF- $\mathrm{kB}$ were found 0.999 and 0.593, respectively (Figure 5a). As shown in Figure 5b, the combined treatment of LA and TRAIL interrupted the binding of XIAP with Caspase3 and NF- $\mathrm{KB}$.

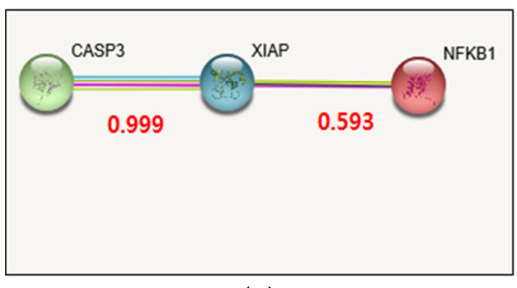

(a)

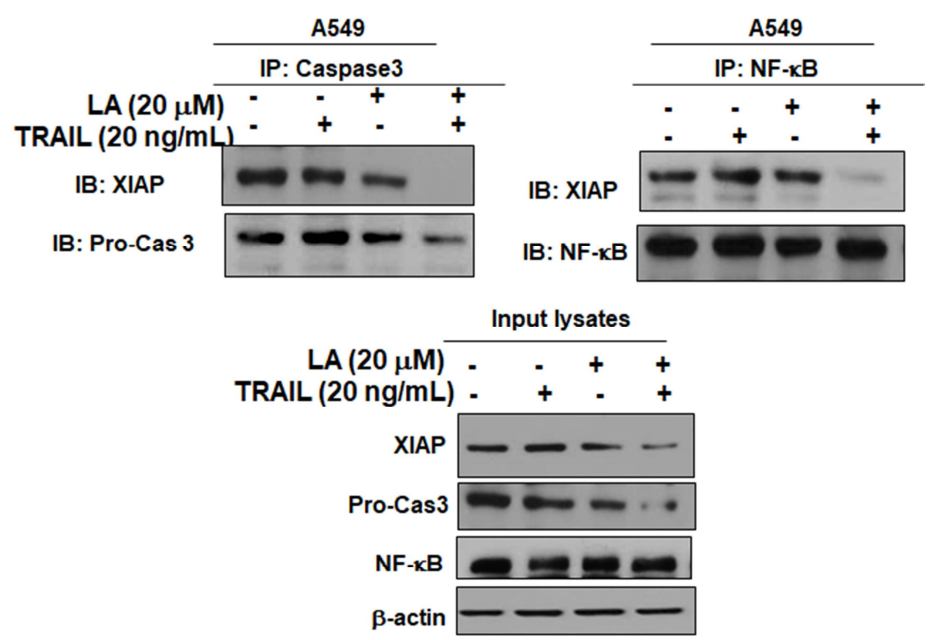

(b)

Figure 5. Combined effect of LA and TRAIL on XIAP interaction with caspase 3 and NF- $\mathrm{BB}$ in A549 non-small cell lung cancer cells. (a) XIAP interacts with caspase 3 and NF- $\kappa B$ in the STRING database. Red text (interaction score). (b) A549 cells were treated with LA ( $20 \mu \mathrm{M})$ and/or TRAIL (20 ng/mL) for $24 \mathrm{~h}$. Immunoprecipitation (IP) was performed with lysates from A549 cells using anti-caspase3 and anti-NF- $\mathrm{B}$ antibodies. Western blot analysis was performed to detect XIAP in whole cell lysates. Western blot analysis was performed to detect XIAP, Pro-cas3, and NF- $\mathrm{KB}$ in input lysates. Input lysates indicated that the $5 \%$ pre-immunoprecipitated samples and $\beta$-actin levels were confirmed as being equivalent to protein loading.

\section{Discussion}

TRAIL is known to play an important role in apoptosis as a therapeutic agent in cancers $[13,14]$. Nevertheless, chemo-resistance to TRAIL has limited its clinical usage in some types of cancers [15]. To overcome this problem, combination treatment has been proposed as an attractive approach by sensitizing TRAIL-mediated cytotoxicity with less side effects [16,17]. In the current study, we investigated whether LA was able to augment TRAIL-induced apoptosis in A549 and H1299 NSCLCs that are resistance to TRAIL treatment.

Here, a combination of LA and TRAIL treatment enhanced cytotoxicity, induced sub-G1 accumulation and the cleavage of PARP, and attenuated the expression of pro-caspase8, pro-caspase9, and pro-caspase 3 compared to LA or TRAIL alone in A549 and H1299 NSCLCs, implying synergistic apoptotic effect by combination of LA and TRAIL.

It was well documented that DR4 upregulation is a promising molecular target for sensitizing tumor cells to TRAIL-induced apoptosis [18]. In our study, the combination of TRAIL and LA activated DR4 in A549 and H1299 cells, implying the potent role of a death-receptor-dependent pathway by combination of TRAIL and LA.

It was reported that tumor cells acquire TRAIL resistance by the upregulation of XIAP, c-FLIP, $\mathrm{Bcl} 2$, and Bcl-xL as antiapoptotic proteins [19,20], and activation of phosphoinositide 3-kinase (PI3K), protein kinase $\mathrm{B}(\mathrm{AKT})$, and NF- $\mathrm{KB}$ as proliferation activators $[21,22]$. Here, the combination of LA and 
TRAIL attenuated the expression of Bcl-2, Bid XIAP, and FLIP in A549 and H1299 cells, implying that the combination of LA and TRAIL inhibits antiapoptotic proteins, leading to apoptosis.

There are accumulating evidences that XIAP, one of the IAP family members, contains a C-terminal RING domain and three distinct baculovirus IAP repeat (BIR) domains $[23,24]$ and plays a critical role in NF-KB activation [25]. The BIR1/TAB1 interaction is crucial for XIAP-induced TAK1 and NF-KB (RelA/p65 and p50 subunits) activation, since the BIR2 domain of XIAP directly blocks the active sites of caspase-3 and caspase-7, while the BIR1 domain directly binds to TAB1 [25-27]. The NF- $\mathrm{kB}$ activation of XIAP is essential for cancer cell survival [25]. Thus, we examined the interaction between XIAP, caspase3, and NF- $\mathrm{kB}$ with a combination treatment of LA and TRAIL in A549 cells. Our results show that the combination of LA and TRAIL attenuated the expression of p-NF-KB and p-IкB and also disrupted the binding of XIAP with caspase 3 or NF-KB in A549 cells, indicating that a combination of LA and TRAIL exerts an apoptotic effect via interrupted binding of XIAP with caspase3 or NF-kB.

In summary, combined treatment of LA and TRAIL increased cytotoxicity and the sub-G1 population in A549 and H1299 NSCLCs, induced apoptosis by cleavage of PARP, and inhibited pro-caspases 8/9/3, Bcl-2, and XIAP, and activated DR4 in A549 and H1299 cells. Furthermore, the combination of TRAIL and LA suppressed the expression of p-NF- $\kappa B$ and p-IкB. Additionally, the combination of TRAIL and LA disrupted the binding of XIAP with caspase3 or NF- $\mathrm{KB}$. Taken together, our findings suggest that the combination of TRAIL and LA synergistically induces apoptosis in non-small cell lung cancer cells via the inhibition of XIAP/NF- KB as a potent TRAIL sensitizer.

\section{Materials and Methods}

\subsection{Lambertianic Acid Isolation}

Pinus koraiensis leaves ( $3 \mathrm{~kg}$ ) were pulverized, immersed in $50 \% \mathrm{MeOH}(10 \mathrm{~L})$ for 3 days, and distilled to be concentrated for $10 \mathrm{~h}$ by using Rotary Evaporator (IKA Korea Limited, Seoul, Korea). Then, $\mathrm{MeOH}$ extracts were partitioned with EtOAc/distilled water (1:1) and the water layer was suspended and partitioned with n-butanol/distilled water. A part of the EtOAc fraction was subjected to celite column chromatography and eluted with $\mathrm{CHCl}_{3}-\mathrm{MeOH}(3: 1)$ to yield 15 fractions. Among these fractions, a distinct and vivid red-purple spot from fr. 6 was isolated, purified, and identified as lambertianic acid (LA) with over $98 \%$ purity, based on spectroscopic analyses such as nuclear magnetic resonance (NMR), mass spectrometry(MS), and infrared (IR) [28].

\subsection{Cell Culture}

Human non-small cell lung cancers A549 and H1299 were obtained from American Type Culture Collection (ATCC). A549 and H1299 cells were cultured in RPMI1640 supplemented with 10\% FBS and $1 \%$ antibiotic (Welgene, Gyeongsan, South Korea).

\subsection{Cytotoxicity Assay}

The cytotoxicity of LA was measured by 3-(4,5-dimethylthiazol-2-yl)-2,5-diphenyltetrazolium bromide (MTT) assay. In brief, A549 and H1299 cells $\left(1 \times 10^{4}\right.$ cells/well $)$ were seeded onto a 96-well culture plate and exposed to various concentrations of LA for $24 \mathrm{~h}$. The cells were incubated with MTT ( $1 \mathrm{mg} / \mathrm{mL}$ ) (Sigma Chemical, St. Louis, MO, USA) for $2 \mathrm{~h}$ and then treated with dimethyl sulfoxide (DMSO) for $20 \mathrm{~min}$. Optical density (OD) was measured using a microplate reader (Molecular Devices Co., San Jose, CA, USA) at $570 \mathrm{~nm}$. Cell viability was calculated as a percentage of viable cells in LA treated group versus untreated control. 


\subsection{Crystal Violet Assay}

For viability and proliferation, crystal violet assay was performed in A549 cells. The cells $\left(2 \times 10^{5}\right.$ cells/well) were seeded onto a $35 \mathrm{~mm}$ culture plate and treated with LA (20 $\left.\mu \mathrm{M}\right)$ and TRAIL (20 ng/mL) for $24 \mathrm{~h}$. The cells were fixed (4\% paraformaldehyde) and stained with crystal violet solution (40\% ethanol, $60 \%$ PBS, and $0.5 \%$ crystal violet). Fifteen minutes later, $1 \mathrm{~mL}$ of $10 \%$ acetic acid was added to each well, and the absorbance was read at $590 \mathrm{~nm}$ using a microplate reader (Molecular Devices Co.).

\subsection{Cell Cycle Analysis}

A549 and H1299 cells $\left(1 \times 10^{6}\right.$ cells $\left./ \mathrm{mL}\right)$ were treated with LA $(0,20 \mu \mathrm{M})$ and TRAIL $(20 \mathrm{ng} / \mathrm{mL})$ for $24 \mathrm{~h}$, washed twice with cold PBS and fixed in $75 \%$ ethanol at $-20^{\circ} \mathrm{C}$. The cells were incubated with RNase A $(10 \mathrm{mg} / \mathrm{mL})$ for $1 \mathrm{~h}$ at $37^{\circ} \mathrm{C}$ and stained with propidium iodide $(50 \mu \mathrm{g} / \mathrm{mL})$ for $30 \mathrm{~min}$ at room temperature in the dark. The stained cells were analyzed for their DNA content by FACSCalibur (Becton Dickinson, Franklin Lakes, NJ, USA) using CellQuest Software (Becton Dickinson, Franklin Lakes, NJ, USA).

\subsection{Western Blotting}

A549 and H1299 cells $\left(1 \times 10^{6}\right.$ cells $\left./ \mathrm{mL}\right)$ were treated with various concentrations of LA for $24 \mathrm{~h}$, lyzed in lysis (50 mM Tris- $\mathrm{HCl}, \mathrm{pH} 7.4,150 \mathrm{mM} \mathrm{NaCl}, 1 \%$ Triton $\mathrm{X}-100,0.1 \%$ SDS, 1 mM EDTA, $1 \mathrm{mM} \mathrm{Na}_{3} \mathrm{VO}_{4}, 1 \mathrm{mM} \mathrm{NaF}$, and $1 \times$ protease inhibitor cocktail) on ice, and spun down at $14,000 \times g$ for $20 \mathrm{~min}$ at $4{ }^{\circ} \mathrm{C}$. The supernatants were collected and quantified for protein concentration by a RC DC protein assay kit (Bio-Rad, Hercules, CA, USA). The proteins samples were separated on 4-12\% NuPAGE Bis-Tris gels (Novex, Carlsbad, CA, USA) and transferred to a Hybond ECL transfer membrane for detection with antibodies for PARP Caspase-8,9,3, DR4, DR5, Bid, p-NF-kB, p-IkB, FLIP, DcR1, DcR2 (Cell Signaling Technology, Beverly, MA, USA), Bcl-2, XIAP (Santa Cruz Biotechnologies, Santa Cruz, CA, USA), and $\beta$-actin (Sigma, St. Louis, MO, USA).

\subsection{Co-Immunoprecipitation}

A549 cells were lyzed in lysis buffer $(50 \mathrm{mM}$ Tris- $\mathrm{HCl}, \mathrm{pH} 7.4,150 \mathrm{mM} \mathrm{NaCl}, 1 \%$ Triton X-100, 0.1\% SDS, $1 \mathrm{mM} \mathrm{NaF,} 1 \mathrm{mM}$ EDTA, $1 \mathrm{mM} \mathrm{Na}_{3} \mathrm{VO}_{4}$, and $1 \times$ protease inhibitor cocktail), and then were immunoprecipitated with caspase3 and NF- $\mathrm{B}$ antibody or normal immunoglobulin G antibody. Thereafter, protein A/G sepharose beads (Santa Cruz Biotechnology, Santa Cruz, CA, USA) were applied. The final precipitated proteins were subjected to immunoblotting with the indicated antibodies.

\subsection{Statistical Analysis}

For the statistical analysis of the data, Sigmaplot version 12 software (Systat Software Inc., San Jose, CA, USA) was used. All data were expressed as means \pm standard deviation (SD). A Student's $t$-test was used for comparison of two groups. The statistically significant difference was set at $p$ values of $<0.05$ between control and LA treated groups.

Author Contributions: D.S.A. and H.J.L. designed and performed several experiments. J.H., H.H., B.K. and B.S. supported experiments. S.-H.K. supervised this experiment and wrote the manuscript.

Acknowledgments: This work was supported by the National Research Foundation of Korea (NRF) and grants funded by the Korea Government (MEST) (No. 2017R1A2A1A17069297).

Conflicts of Interest: The authors declare no conflict of interest. 


\section{Abbreviations}

$\begin{array}{ll}\text { TRAIL } & \text { TNF-related apoptosis-inducing ligand } \\ \text { PARP } & \text { Poly (ADP-ribose) polymerase } \\ \text { Caspase } & \text { Cysteine aspartyl-specific protease } \\ \text { Bcl-2 } & \text { B-cell lymphoma } 2 \\ \text { XIAP } & \text { X-linked inhibitor of apoptosis protein } \\ \text { DR5 } & \text { Death receptor5 } \\ \text { NF-KB } & \text { Nuclear factor kappa-light-chain-enhancer of } \\ & \text { activated B cells }\end{array}$

\section{References}

1. Secchiero, P.; Vaccarezza, M.; Gonelli, A.; Zauli, G. TNF-related apoptosis-inducing ligand (TRAIL): A potential candidate for combined treatment of hematological malignancies. Curr. Pharm. Des. 2004, 10, 3673-3681. [CrossRef] [PubMed]

2. Wang, S.; El-Deiry, W.S. TRAIL and apoptosis induction by TNF-family death receptors. Oncogene 2003, 22, 8628-8633. [CrossRef] [PubMed]

3. Walczak, H. Death receptor-ligand systems in cancer, cell death, and inflammation. Cold Spring Harb. Perspect. Biol. 2013, 5, a008698. [CrossRef] [PubMed]

4. Refaat, A.; Abd-Rabou, A.; Reda, A. TRAIL combinations: The new 'trail' for cancer therapy (Review). Oncol. Lett. 2014, 7, 1327-1332. [CrossRef] [PubMed]

5. Lim, S.C.; Parajuli, K.R.; Han, S.I. The alkyllysophospholipid edelfosine enhances TRAIL-mediated apoptosis in gastric cancer cells through death receptor 5 and the mitochondrial pathway. Tumour Biol. 2016, 37, 6205-6216. [CrossRef] [PubMed]

6. Kim, J.; Yun, M.; Kim, E.O.; Jung, D.B.; Won, G.; Kim, B.; Jung, J.H.; Kim, S.H. Decursin enhances TRAIL-induced apoptosis through oxidative stress mediated- endoplasmic reticulum stress signalling in non-small cell lung cancers. Br. J. Pharmacol. 2016, 173, 1033-1044. [CrossRef] [PubMed]

7. Zhao, Y.; Tian, B.; Wang, Y.; Ding, H. Kaempferol Sensitizes Human Ovarian Cancer Cells-OVCAR-3 and SKOV-3 to Tumor Necrosis Factor-Related Apoptosis-Inducing Ligand (TRAIL)-Induced Apoptosis via JNK/ERK-CHOP Pathway and Up-Regulation of Death Receptors 4 and 5. Med. Sci. Monit. 2017, 23, 5096-5105. [CrossRef] [PubMed]

8. Min, K.J.; Um, H.J.; Seo, S.U.; Woo, S.M.; Kim, S.; Park, J.W.; Lee, H.S.; Kim, S.H.; Choi, Y.H.; Lee, T.J.; et al. Angelicin potentiates TRAIL-induced apoptosis in renal carcinoma Caki cells through activation of caspase 3 and down-regulation of c-FLIP expression. Drug Dev. Res. 2018, 79, 3-10. [CrossRef] [PubMed]

9. Yang, X.; Li, Z.; Wu, Q.; Chen, S.; Yi, C.; Gong, C. TRAIL and curcumin codelivery nanoparticles enhance TRAIL-induced apoptosis through upregulation of death receptors. Drug Deliv. 2017, 24, 1526-1536. [CrossRef] [PubMed]

10. Lee, M.S.; Cho, S.M.; Lee, M.H.; Lee, E.O.; Kim, S.H.; Lee, H.J. Ethanol extract of Pinus koraiensis leaves containing lambertianic acid exerts anti-obesity and hypolipidemic effects by activating adenosine monophosphate-activated protein kinase (AMPK). BMC Complement. Altern. Med. 2016, 16, 51. [CrossRef] [PubMed]

11. Chae, H.S.; Chin, Y.W. Anti-allergic effect of lambertianic acid from Thuja orientalis in mouse bone marrow-derived mast cells. Immunopharmacol. Immunotoxicol. 2012, 34, 250-255. [CrossRef] [PubMed]

12. Jeong, A.; Kim, J.H.; Lee, H.J.; Kim, S.H. Reactive oxygen species dependent phosphorylation of the liver kinase B1/AMP activated protein kinase/acetyl-CoA carboxylase signaling is critically involved in apoptotic effect of lambertianic acid in hepatocellular carcinoma cells. Oncotarget 2017, 8, 70116-70129. [CrossRef] [PubMed]

13. Wang, S. The promise of cancer therapeutics targeting the TNF-related apoptosis-inducing ligand and TRAIL receptor pathway. Oncogene 2008, 27, 6207-6215. [CrossRef] [PubMed]

14. Ferguson, T.A.; Griffith, T.S. The role of Fas ligand and TNF-related apoptosis-inducing ligand (TRAIL) in the ocular immune response. Chem. Immunol. Allergy 2007, 92, 140-154. [PubMed]

15. Trivedi, R.; Mishra, D.P. Trailing TRAIL Resistance: Novel Targets for TRAIL Sensitization in Cancer Cells. Front. Oncol. 2015, 5, 69. [CrossRef] [PubMed] 
16. De Miguel, D.; Lemke, J.; Anel, A.; Walczak, H.; Martinez-Lostao, L. Onto better TRAILs for cancer treatment. Cell Death Differ. 2016, 23, 733-747. [CrossRef] [PubMed]

17. Dimberg, L.Y.; Anderson, C.K.; Camidge, R.; Behbakht, K.; Thorburn, A.; Ford, H.L. On the TRAIL to successful cancer therapy? Predicting and counteracting resistance against TRAIL-based therapeutics. Oncogene 2013, 32, 1341-1350. [CrossRef] [PubMed]

18. Zhou, J.; Lu, G.D.; Ong, C.S.; Ong, C.N.; Shen, H.M. Andrographolide sensitizes cancer cells to TRAIL-induced apoptosis via p53-mediated death receptor 4 up-regulation. Mol. Cancer Ther. 2008, 7, 2170-2180. [CrossRef] [PubMed]

19. Tang, S.Y.; Zhong, M.Z.; Yuan, G.J.; Hou, S.P.; Yin, L.L.; Jiang, H.; Yu, Z. Casticin, a flavonoid, potentiates TRAIL-induced apoptosis through modulation of anti-apoptotic proteins and death receptor 5 in colon cancer cells. Oncol. Rep. 2013, 29, 474-480. [CrossRef] [PubMed]

20. Baritaki, S.; Suzuki, E.; Umezawa, K.; Spandidos, D.A.; Berenson, J.; Daniels, T.R.; Penichet, M.L.; Jazirehi, A.R.; Palladino, M.; Bonavida, B. Inhibition of Yin Yang 1-dependent repressor activity of DR5 transcription and expression by the novel proteasome inhibitor NPI-0052 contributes to its TRAIL-enhanced apoptosis in cancer cells. J. Immunol. 2008, 180, 6199-6210. [CrossRef] [PubMed]

21. Lirdprapamongkol, K.; Sakurai, H.; Suzuki, S.; Koizumi, K.; Prangsaengtong, O.; Viriyaroj, A.; Ruchirawat, S.; Svasti, J.; Saiki, I. Vanillin enhances TRAIL-induced apoptosis in cancer cells through inhibition of NF- $\mathrm{kB}$ activation. In Vivo 2010, 24, 501-506. [PubMed]

22. Franco, A.V.; Zhang, X.D.; Van Berkel, E.; Sanders, J.E.; Zhang, X.Y.; Thomas, W.D.; Nguyen, T.; Hersey, P. The role of NF- $\mathrm{K}$ B in TNF-related apoptosis-inducing ligand (TRAIL)-induced apoptosis of melanoma cells. J. Immunol. 2001, 166, 5337-5345. [CrossRef] [PubMed]

23. Cao, Z.; Li, X.; Li, J.; Luo, W.; Huang, C.; Chen, J. X-linked inhibitor of apoptosis protein (XIAP) lacking RING domain localizes to the nuclear and promotes cancer cell anchorage-independent growth by targeting the E2F1/Cyclin E axis. Oncotarget 2014, 5, 7126-7137. [CrossRef] [PubMed]

24. Liston, P.; Fong, W.G.; Korneluk, R.G. The inhibitors of apoptosis: There is more to life than Bcl2. Oncogene 2003, 22, 8568-8580. [CrossRef] [PubMed]

25. Lu, M.; Lin, S.C.; Huang, Y.; Kang, Y.J.; Rich, R.; Lo, Y.C.; Myszka, D.; Han, J.; Wu, H. XIAP induces NF-кB activation via the BIR1/TAB1 interaction and BIR1 dimerization. Mol. Cell 2007, 26, 689-702. [CrossRef] [PubMed]

26. Gyrd-Hansen, M.; Meier, P. IAPs: From caspase inhibitors to modulators of NF- $\kappa B$, inflammation and cancer. Nat. Rev. Cancer 2010, 10, 561-574. [CrossRef] [PubMed]

27. Liu, Y.; Chen, X.D.; Yu, J.; Chi, J.L.; Long, F.W.; Yang, H.W.; Chen, K.L.; Lv, Z.Y.; Zhou, B.; Peng, Z.H.; et al. Deletion Of XIAP reduces the severity of acute pancreatitis via regulation of cell death and nuclear factor- $\mathrm{KB}$ activity. Cell Death Dis. 2017, 8, e2685. [CrossRef] [PubMed]

28. Yang, X.; Ding, Y.; Sun, Z.H.; Zhang, D.M. Studies on chemical constituents of Pinus armandii. Yao Xue Xиe Bao 2005, 40, 435-437. [PubMed]

(C) 2018 by the authors. Licensee MDPI, Basel, Switzerland. This article is an open access article distributed under the terms and conditions of the Creative Commons Attribution (CC BY) license (http:// creativecommons.org/licenses/by/4.0/). 